\title{
KAJIAN TEORITIS ASPEK EPISTEMOLOGI DALAM PENERAPAN HUKUM
}

\author{
Tengku Erwinsyahbana \\ Ramlan \\ Vivi lia Falini Tanjung \\ Program Magister Kenotariatan \\ Universitas Muhammadiyah Sumatera Utara \\ Email: erwin6768@gmail.com
}

\begin{abstract}
Abstrak
Epistemologi merupakan cabang filsafat, yang sebenarnya mengkaji hakikat pengetahuan yang khusus untuk 4 (empat) pokok persoalan pengetahuan seperti keabsahan, struktur, batas, serta sumber pengetahuan, dan dalam pengkajian ilmu hukum maka hal ini termasuk wilayah kajian epistemologi. Aspek epistemologis ilmu hukum tampak dalam proses penyelesaian kasus yang terbagi ke dalam beberapa langkah. Proses tersebut mencakup memaparkan, menginterpretasi, mensistematisasi bahan-bahan hukum yang terdiri asas-asas, aturan-aturan dan putusan-putusan hukum untuk menetapkan hukum yang berlaku atas masalah hukum yang timbul. Penyelesaian kasus tidak dimulai dengan aturan-aturan hukum, melainkan dimulai dengan masalah, yang berupa memaparkan sejumlah fakta, hubungan-hubungan dan kejadian-kejadian yang di dalamnya tersembunyi satu atau lebih masalah yuridis.
\end{abstract}

Kata Kunci: Epistemologi, Filsafat, Ilmu Pengetahuan.

\section{A. Pendahuluan}

Manusia sebagai makhluk yang mempunyai akal, selalu mempunyai rasa ingin tahu atas segala sesuatu yang ada di hadapannya. Rasa keingintahuan itu selalu muncul dengan suatu kata tanya: siapa, dimana, apa, bagaimana, mengapa dan berbagai kata tanya lainnya. Kalau dalam diri manusia muncul pertanyaan-pertanyaan mendasar seperti ini, maka manusia selalu akan berusaha memperoleh jawabannya dan pada saat itu dapat dikatakan bahwa dirinya telah berfilsafat dalam pengertian sederhana. Filsafat adalah istilah yang berasal dari bahasa Yunani, yaitu filosofia, yang berarti melihat segala sesuatu dengan perhatian atau minat ataupun berarti berpikir tentang segala sesuatu dan keadaan yang berpikir seperti itu disadarinya. ${ }^{1}$ Hasil pikiran manusia ini dapat diperolehnya cukup hanya dengan menanyakan jawaban atas sesuatu masalah

1 Judistira K. Garna (1), Teori Sosial Pembangunan I, Primaco Akademika dan Judistira Garna Foundation, Bandung, 2006, hlm. 1. 
kepada orang lain, mengamati, melakukan observasi ataupun dengan cara lainnya. Bahkan buah pikiran itu dapat dihasilkan dengan menggunakan metodemetode tertentu yang lazim dikenal dengan istilah metode ilmiah.

Metode ilmiah merupakan prosedur dalam mendapatkan pengetahuan yang disebut ilmu. ${ }^{2}$ Berpikir secara ilmiah berarti berfilsafat. Menurut Judistira K. Garna bahwa karakteristik berpikir filsafat itu adalah berpikir yang bersifat: ${ }^{3}$

1. Menyeluruh, artinya seseorang itu tidak puas lagi mengenal ilmu hanya dari sisi pandang ilmu tersebut, ingin melihat ilmu dari konstelasi pengetahuan yang lainnya, kaitan ilmu dengan moral, kaitan ilmu dengan agama. Ingin yakin apakah ilmu itu membawa kebahagiaan bagi diri.

2. Mendasar, berpikir filsafat itu membongkar tempat berpijak secara fundamental, tidak lagi percaya demikian saja bahwa ilmu itu benar, yang lebih jauh dipertanyakan: mengapa ilmu dapat disebut benar, bagaimana proses penilaian berdasarkan kriteria benar itu dilakukan, apakah kriteria itu sendiri benar, bagaimana proses penilaian menurut kriteria itu dilakukan dan benar itu apa.

3. Spekulatif, kecurigaan terhadap filsafat itu bukanlah spekulasi, tetapi itu merupakan suatu dasar yang tidak bisa diadakan, karena itu suatu lingkaran (bahwa pertanyaan itu melingkar, sedangkan untuk menyusun lingkaran harus dimulai dari satu titik), maka suatu pertanyaan masalah harus mulai dari satu titik bagaimanapun spekulatifnya. Hal penting dalam prosesnya atau dalam analisis dan pembuktian dapat dipisahkan manakah yang spekulasi dan manakah yang dapat atau tidak dapat diandalkan. Dengan demikian tugas utama filsafat ialah menetapkan dasar yang dapat diandalkan tersebut. Kemudian timbul pertanyaan yang perlu jawaban, yaitu apakah yang disebut logik, benar, sahih dan apakah teratur, hidup itu bertujuan dan apakah hukum yang mengatur alam dan segenap satwa kehidupan ini.

Dapat dikatakan bahwa filsafat dalam arti luas, adalah segala bentuk reflektivitas kritis manusia, yang tanpa bisa dibungkam terus menerus mempertanyakan makna dari segala yang dialaminya dan senantiasa berusaha membentuk peta besar tentang hakekat totalitas kehidupan. Dalam alam pra-

\footnotetext{
2 Jujun S. Suriasumantri, Filsafat IImu Sebuah Pengantar Populer, Cetakan Keduabelas, Pustaka Sinar Harapan, Jakarta, 1999, hIm. 119.

${ }^{3}$ Judistira K. Garna (2), Filsafat IImu, Primaco Akademika dan Judistira Garna Foundation, Bandung, 2006, hlm. 8-9.
} 
modern ia menyatu dengan unsur agama dan seni. Dalam dunia modern ia terpisah dan mandiri, lalu pada tingkat praktis melahirkan sains, sedankan sains melahirkan teknologi dan ekonomi. Perkembangan sains, teknologi dan ekonomi telah menjadikan hidup manusia dikendalikan oleh ketiganya itu. Filsafat, posisi ilmiahnya digugat, tendensi ideologisnya dicurigai, karakter spekulatifnya dijadikan bahan olok-olok, tetapi sebagai upaya tidak berkesudahan untuk memburu hakikat terdalam kenyataan, serta upaya untuk memetakan kembali setiap kali persoalan-persoalan eksistensial terselubung semata-mata berdasarkan akal sehat dan pengalaman, filsafat tetaplah sangat penting dan sesungguhnya tidak akan pernah hilang. Sebagaimana yang dikemukakan lebih lanjut oleh Judistira K. Garna, bahwa apabila filsafat itu tempat untuk berspekulasi, maka filsafat merupakan tempat pijakan dari ilmu, termasuk berbagai cabang ilmu yang dapat dikatakan sebagai kegiatan dari ilmu, ${ }^{4}$ sedangkan ilmu pada dasarnya merupakan kumpulan pengetahuan bersifat penjelasan gejala alam yang memungkinkan manusia melakukan rangkaian tindakan untuk menguasai gejala alam berdasarkan penjelasan yang ada. ${ }^{5}$

Mungkin bagi manusia zaman sekarang, ilmu bukan lagi sesuatu hal yang mengagumkan, kalaupun masih tersisa kekaguman, maka kekaguman ini bercampur dengan rasa kecemasan dan kecurigaan. Hal yang mencemaskan dan mencurigakan bukan hanya terbatas pada akibat-akibat negatif yang ditimbulkannya, melainkan sesuatu yang lebih mendasar, yakni sisi idiologis, kerangka dasar epistemologis, serta doktrin-doktrin metodologisnya. Oleh sebab itu, untuk menghilangkan kecemasan dan kecurigaan demikian, maka perlu diperhatikan landasan epistemologi, sehingga ilmu pengetahuan dapat diperoleh secara benar.

\section{B. Landasan Epistemologi dalam IImu Pengetahuan}

Bagaimanapun pengetahuan manusia selalu mengalami pergerakan, yang oleh van Peursen dibagi menjadi tiga tahap, yakni tahap mistis, tahap ontologis dan tahap fungsionil. ${ }^{6}$ Yang dimaksud dengan tahap mistis adalah sikap manusia dalam memahami gejala-gejala alam memposisikan dirinya

\footnotetext{
${ }^{4}$ Ibid., hlm. 9. 25.

5 Judistira K. Garna (3), Filsafat Ilmu, Program Pascasarjana Unpad, Bandung, 2008, hlm.

${ }^{6}$ C.A. van Peursen, Strategi Kebudayaan, Kanisius, Yogyakarta, 1988, hlm. 18.
} 
sebagai mahluk yang terkepung oleh kekuatan-kekuatan gaib sekitarnya, yaitu kekuasaan dewa-dewa alam raya atau kekuasaan kesuburan, seperti terwujud dalam mitos-mitos. Pada tahap ini manusia memahami peristiwa alam seperti bencana alam atau panen sebagai hasil dari kekuatan-kekuatan mistis di mana manusia tidak dapat menghindarinya. Manusia mencoba memahaminya dengan mempersonifikasikan pada dewa-dewa sebagai penyebab terjadinya peristiwa alam. Upacara keagamaan menjadi penting guna memberikan persembahan pada dewa-dewa agar tetap memberikan perlindungan kepada manusia dan menjauhkannya dari bencana. Oleh karena itu, menurut Peursen, salah satu fungsi mitos adalah memberikan pengetahuan tentang dunia, selain sebagai pedoman tertentu bagi sekelompok orang dan untuk memberikan jaminan bagi masa kini. ${ }^{7}$

Pada tahap ontologis, manusia dalam memahami gejala-gejala alam tidak lagi dalam posisi terkepung oleh kekuasaan mistis, melainkan secara bebas mampu meneliti segala sesuatu hal. Yang merupakan ciri pada tahap ini yaitu manusia mulai mengambil jarak terhadap objek, ia mengamat-amati dan mengkotak-kotakkan. Dalam melukiskan dunia, yang semula dihubungkan dengan kekuasaan para dewa, kemudian digantikannya dengan sebuah ajaran atau teori mengenai dasar hakikat segala sesuatu (ontologi), termasuk dalam melukiskan alam semesta. Ajaran-ajaran mitologis mengenai terjadinya dewa-dewa diubah menjadi filsafat atau ilmu mengenai dunia yang tidak nampak (metafisika), gambaran-gambaran mitologis mengenai terjadinya dunia ini dialihkan menjadi ajaran filosofis mengenai alam raya (filsafat fisika), pembersihan batin yang berhadapan dengan kesalahan tragis (katharsis) harus minggir bagi filsafat etika. Dengan demikian tata tertib alam semesta dapat diterima manusia lewat jalan pengertian dan pengetahuan. ${ }^{8}$

Terakhir dalam tahap fungsionil, ialah sikap dan alam pikiran yang tidak terpesona lagi oleh lingkungannya (sikap mistis), tidak lagi dengan kepala dingin ambil jarak terhadap objek penelitiannya. Sebaliknya manusia mengadakan relasi-relasi baru, suatu ketertautan yang baru terhadap segala sesuatu dalam lingkungannya. ${ }^{9}$ Menurut Peursen yang merupakan satu sikap dasar dalam sikap

\footnotetext{
${ }^{7}$ Ibid., hlm. 37-54.

${ }^{8}$ Ibid., hlm. 58.

${ }^{9}$ lbid., hlm. 18.
} 
fungsionil adalah bahwa orang mencari hubungan-hubungan antara semua bidang, arti sebuah kata atau sebuah perbuatan maupun barang dipandang menurut peran atau fungsi yang dimainkan dalam keseluruhan itu yang saling bertautan. ${ }^{10}$ Sebagai contoh, bahwa norma yang mewajibkan kita harus patuh pada orang tua tidak lagi dipahami dengan menerimanya begitu saja karena berabad-abad lamanya sudah berlaku, yang seolah-olah merupakan hukumhukum abadi. Norma-norma dipahami dengan dengan mencari apa arti atau pesan norma-norma tersebut bagi manusia. Proses pencarian arti atau makna tersebut bukannya dengan mengambil jarak terhadap norma-norma itu yang kemudian dirumuskan dalam pengertian umum dan abstrak seperti dalam alam pikiran ontologis, melainkan berkaitan dengan meleburkan diri pada situasisituasi konkrit melalui tindakan-tindakan nyata.

Pada awalnya manusia manusia terkepung oleh kekuatan mistis, tetapi dalam perkembangan berikutnya ia berusaha melepaskan diri dari kekuatan tersebut. Hal ini dimungkinkan karena sebagai makhluk yang mulia, manusia diberikan akal oleh Tuhan dan dengan akalnya itu manusia selalu terus berusaha menemukan jawaban atas fenomena sekelilingnya. Dengan adanya akal, manusia mempunyai kemampuan untuk menalar. Kemampuan ini menyebabkan manusia mampu mengembangkan pengetahuan secara sungguh-sungguh dan dia akan memikirkan hal-hal yang baru demi kelangsungan hidupnya.

Kemampuan mengembangkan pengetahuannya dengan cepat, karena kemampuan berpikir manusia yang mengikuti suatu alur kerangka tertentu. Secara garis besar cara berpikir seperti disebut penalaran. ${ }^{11}$ Penalaran merupakan proses berpikir dalam menarik sesuatu kesimpulan yang berupa pengetahuan. ${ }^{12}$ Dalam melakukan penalaran ini ada beberapa hal yang perlu diperhatikan sebagai pedoman, seperti cara/teknik dan sarana yang digunakan, sehingga diperoleh pengetahuan yang disebut ilmu. Untuk menemukan pengetahuan inilah digunakan salah satu cabang filsafat yang disebut epistemologi. Dengan demikian, untuk mendapatkan pengetahuan secara benar, maka sebagai landasan epistemologi, ada 5 (lima) pertanyaan mendasar yang perlu diperhatikan, yaitu: ${ }^{13}$

\footnotetext{
${ }_{11}^{10}$ Ibid., hlm. 86.

11 Jujun S. Suriasumantri, Op. Cit., hlm. 40.

12 Ibid., hlm. 42.

${ }^{13}$ Judistira K. Garna (3) , Op. Cit., hlm. 12.
} 
1. Bagaimana prosedurnya.

2. Hal apa yang diperhatikan agar memperoleh pengetahuan yang benar.

3. Apa yang disebut kebenaran.

4. Apa kriteria kebenaran itu.

5. Cara, teknik, sarana apa yang membantu memperoleh pengetahuan yang disebut ilmu itu.

Epistemologi merupakan cabang filsafat, yang sebenarnya mengkaji hakikat pengetahuan yang khusus untuk 4 (empat) pokok persoalan pengetahuan seperti keabsahan, struktur, batas dan sumber pengetahuan. Secara etimologi, penguraian berdasarkan pada asal katanya, istilah epistemologi berasal dari bahasa Yunani, yaitu episteme dan logos. Episteme artinya pengetahuan dan logos lazim dipakai untuk menunjukkan adanya pengetahuan sistematis. Secara sederhana epistemologi diartikan sebagai pengetahuan mengenai pengetahuan. Episteme berasal dari kata kerja epistamai, artinya mendudukan, menempatkan atau meletakkan. Secara harfiah episteme berarti pengetahuan sebagai upaya intelektual untuk menempatkan sesuatu dalam kedudukan setepatnya. ${ }^{14}$

Anthony Flew dalam A Dictionary of Philosophy menjelaskan bahwa epistemologi sebagai: "The branch of philosophy concerned with the theory of knowledge. Traditionally, central issues in epistemology are the nature and derivation of knowledge, the scope of knowledge and the reliability of claims to knowledge". ${ }^{15}$

Selain kata episteme, untuk kata pengetahuan dalam bahasa Yunani juga dipakai kata gnosis, maka istilah epistemologi dalam sejarah pernah juga disebut gnoseologi sebagai kajian filosofis yang membuat telaah kritis dan analitis tentang dasar-dasar teoritis pengetahuan. Dalam bahasa Jerman, epistemologi diterjemahkan antara lain menjadi erkentnistheorie dan dalam bahasa Belanda dikenal istilah kennisleer atau kentheorien (teori pengetahuan). ${ }^{16}$ Berdasarkan asal kata dan pengertiannya, singkatnya dapat disebutkan bahwa epistemologi

${ }^{14}$ A.M.W. Pranarka, Epistemologi Dasar, Centre For Strategic and International Studies (CSIS), Jakarta, 1987, hlm. 4. Press, t.t, hlm. 101.

${ }^{16} \mathrm{~J}$. Sudarminta, Epistemologi Dasar, Kanisius, Yogyakarta, 2002, hlm.18-19. 
adalah salah satu cabang filsafat untuk membantu bagaimana cara mendapatkan pengetahuan yang disebut ilmu.

\section{Aspek Epistemologis dalam IImu Hukum}

Hukum sebagai gejala sosial yang menampakkan aspek, fase, ciri, dimensi ruang dan waktu, serta tataran analisis yang majemuk merupakan obyek studi dengan melakukan kegiatan ilmiah dari berbagai sudut pandang dan pendekatan. Misalnya telaah tentang hukum dengan melihat bagaimana hukum tersebut tampak dalam sikap dan perilaku warga masyarakat dalam aktivitas berlalulintas dan angkutan jalan, artinya studi tersebut terarah pada kegiatan ilmiah dengan objek telaah hukum dari sudut pandang dan pendekatan sosiologis.

Kegiatan ilmiah di bidang hukum yang dilakukan dengan menggunakan berbagai sudut pandang dan pendekatan tersebut selanjutnya melahirkan berbagai disiplin ilmiah yang mandiri yang masing-masing objek telaahnya hukum. Disiplin ilmiah yang dimaksud adalah kegiatan intelektual untuk secara rasional memperoleh pengetahuan dalam bidang hukum secara sistematis dan terikat pada aturan prosedur (metode) tertentu. Dengan demikian terdapat beberapa disiplin hukum yang masing-masing dari sudut pandang tertentu berusaha memperoleh pemahaman teoritis atau penguasaan intelektual terhadap atau berkenaan dengan hukum. ${ }^{17}$ Misalnya penelaahan terhadap hukum yang dilakukan berdasarkan pada sudut pandang dan pendekatan serta metode dan pengertian-pengertian yang khas digunakan dalam sosiologi sebagai disiplin induknya, yang akan melahirkan sosiologi hukum sebagai disiplin ilmiah mandiri.

Keseluruhan disiplin ilmiah tersebut dapat disebut dalam satu istilah, yaitu disiplin ilmiah tentang hukum (science concerned with law), ilmu hukum (jurisprudence) atau pengembanan hukum teoritikal (theoritische rechtsbeoefening). Sekali lagi istilah-istilah tersebut semuanya menunjuk pada kegiatan akal budi untuk secara ilmiah (rasional-sistematikal-metodikal, terargumentasi dan terus menerus) berupaya memperoleh pengetahuan tentang hukum dan penguasaan intelektual atas hukum. ${ }^{18}$

17 B. Arief Sidharta (1), Refleksi tentang Struktur IImu Hukum, Mandar Maju, Bandung, 2000, hlm. 136.

${ }^{18}$ B. Arief Sidharta (2), "Disiplin Hukum: Tentang Hubungan Antara Ilmu Hukum, Teori Hukum dan Filsafat Hukum", Pro Justitia, Tahun XX, B. Arief Sidharta, No. 3, Juli 2002, hlm. 4. 
Ilmu hukum mempunyai tujuan memberi suatu pengetahuan dan kemampuan penguasaan intelektual tentang hukum baik terhadap pembentuk undang-undang, terhadap hakim maupun para ilmuwan hukum. Pengetahuan yang dimaksud adalah pengetahuan hukum yang dimiliki dalam mempersiapkan pengambilan putusan hukum konkrit yang akan dibuatnya, yakni menetapkan hak dan kewajiban orang dalam situasi kemasyarakatan konkrit tertentu berdasarkan kaidah hukum yang tercantum dalam suatu aturan hukum, yang kepatuhannya tidak diserahkan pada kehendak bebas orang yang bersangkutan, melainkan dapat dipaksakan oleh otoritas publik. Dengan demikian ilmu hukum memiliki pretensi untuk memberikan solusi atau penyelesaian hukum konkrit, artinya memberi jawaban atas pertanyaan apa hukumnya yang berlaku bagi kenyataan-kenyataan kemasyarakatan tertentu yang menimbulkan masalah hukum.

Tujuan ilmu pengetahuan hukum termasuk ilmu hukum positif adalah untuk memahami dan menguasai pengetahuan tentang kaidah dan asas-asas untuk kemudian dapat mengambil keputusan berdasarkan hal tersebut. ${ }^{19}$ IImu pengetahuan hukum dalam aplikasinya dapat dikelompokkan pada tiga kegiatan, yang antara lain terdiri dari:

1. Pembentukan hukum, kegiatan ini mencakup pembentukan peraturan perundang-undangan oleh lembaga tertentu yang berwenang melalui prosedur tertentu yang sebelumnya telah ditetapkan. Perundang-undangan adalah bentuk pembentukan hukum yang paling penting yang di dalamnya diciptakan suatu model perilaku abstrak yang di kemudian hari dapat dipergunakan untuk dapat menyelesaikan masalah-masalah kemasyarakatan konkrit. Selain itu pembentukan hukum dapat dilakukan oleh hakim dalam sebuah proses peradilan dimana terhadap kasus yang dihadapinya tidak terdapat suatu aturan hukum yang mengaturnya. Sering kali hal tersebut dilakukan hakim melalui suatu metode konstruksi hukum yang terdiri dari metode argumentum peranalogian (analogi), argumentum a contrario dan metode penghalusan hukum (rechtsvervijnings). ${ }^{20}$

\footnotetext{
${ }^{19}$ Mochtar Kusumaatmadja dan B. Arief Sidharta, Pengantar IImu Hukum, Buku I, Alumni, Bandung, 2000, hlm. 6-7. hlm. 67-71.
} 
2. Penerapan hukum, kegiatan ini untuk menentukan hukum apa yang diterapkan bagi peristiwa hukum tertentu berdasarkan kaidah-kaidah hukum yang berlaku. Dalam penerapan hukum kegiatan penemuan hukum memegang peranan penting, karena dengannya kaidah hukum dan jangkauan keberlakuan dari suatu aturan hukum diperoleh dan kemudian diterapkan pada peristiwa hukum yang dihadapi untuk kemudian ditetapkan apa akibat hukumnya bagi peristiwa hukum tersebut. Penerapan hukum ini dapat berbentuk putusan-putusan hakim, ketetapan, pembuatan akta oleh notaris dan lain sebagainya.

3. Perkembangan hukum. Hukum mengembangkan diri dengan suatu kerja sama yang kompleks antara pembentuk undang-undang, hakim dan ilmu hukum. Ilmu hukum sering mempelajari hukum dengan mengambil pengertian-pengertian dalam hukum yang sudah tersedia dalam undangundang, tetapi di lain pihak para pembentuk undang-undang sering mengambil pengertian-pengertian tersebut sebagai hasil kerja ilmu hukum dan memasukannya dalam rumusan undang-undang. Perkembangan hukum diperoleh melalui kerjasama antara ilmu hukum dengan hakim. Putusan hakim yang telah memperoleh anotasi (pandangan dan penilaian hukum) dari ilmuwan hukum sering menjadi celah untuk perkembangan hukum yang di kemudian hari dapat diletakkan sebagai landasan dari putusannya.

Melakukan analisis hukum terhadap fakta akan menarik perhatian, mengingat hal tersebut tidak sesederhana yang dibayangkan orang pada umumnya yang hanya mengandalkan pada kegiatan seorang hakim dalam menerapkan aturan-aturan hukum yang ada pada setiap peristiwa konkrit yang terjadi, meskipun hingga derajat tertentu hakim memang melakukannya demi menjaga konsistensi yuridikal, dan harus pula dipahami bahwa jika dikaitkan dengan sistem hukum, maka tidak hanya berbicara mengenai hubungan antara peraturan yang satu dengan yang lainnya, tetapi termasuk juga di dalamnya lembaga atau organisasi yang mempunyai otorisasi untuk membentuk dan menjalankan sistem hukum tersebut. ${ }^{21}$

Hukum bukanlah barang yang tersedia begitu saja yang setiap saat oleh hakim dapat diterapkan terhadap fakta. Begitu juga terhadap berbagai peristiwa

${ }^{21}$ Tengku Erwinsyahbana, "Sistem Hukum Perkawinan pada Negara Hukum Berdasarkan Pancasila”, Jurnal IImu Hukum, Fakultas Hukum-Universitas Riau, Pekanbaru, 2012, hlm. 170. 
yang terjadi tidak dapat begitu saja hakim langsung dapat menderivasi aturanaturan hukum yang ada tanpa memperhatikan situasi problematikal yang melingkupi peristiwa tersebut. Seperti halnya berpikir silogisme dalam metode penalaran hukum, ketidaksederhanaan nampak dimana aturan hukum yang dipandang sebagai premis mayor selalu memerlukan kualifikasi atau interpretasi dalam konteks kenyataan faktual yang konkrit. Premis minornya berupa fakta yuridis, yakni fakta-fakta dari sebuah kasus dalam masalah hukum juga tidak begitu saja dapat ditetapkan, melainkan harus dipersepsi dan dikualifikasi dalam konteks aturan hukum yang relevan untuk kemudian diseleksi dan dikualifikasi berdasarkan kategori-kategori hukum. ${ }^{22}$

Van Peursen menyatakan bahwa fakta itu tidak ditemukan seperti objek atau benda tertentu yang dipungut dari tanah, melainkan fakta adalah hasil pengamatan, penjelasan teoritis, usaha yang bersifat membatasi dari disiplin ilmiah tertentu. Selanjutnya ia mengatakan bahwa fakta tidak ditemukan, melainkan dijadikan, ${ }^{23}$ sehingga setiap pengetahuan manusia tentang kenyataan apapun adalah pengetahuan hasil interpretasi, dalam arti sudah bermuatan teori dan pengandaian-pengandaian dan karena itu sesungguhnya tidak pernah murni objektif dan netral. ${ }^{24}$

Seperti yang dikatakan Gadamer bahwa interpretasi memiliki pra-struktur di dalam pemahaman, yakni vorhabe (apa yang sudah dimiliki sebelumnya), vorsicht (apa yang sudah dilihat sebelumnya), vorgriff (apa yang ditangkap sebelumnya). Jika seseorang mengetahui sesuatu, maka bagaimanapun objek pengetahuan tersebut pasti mendapat pengaruh dari subjek yang mengetahui, karena itu sesungguhnya fakta yang bebas nilai, bebas prasangka dan bebas kepentingan itu tidak pernah ada.

Dalam kegiatan pengembangan ilmu hukum, usaha memperoleh pengetahuan tentang hukum yang di dalamnya mencakup kegiatan mengkualifikasi fakta dan menetapkan hukum dan seorang ilmuwan hukum tidak pernah bertolak dari suatu pengetahuan yang kosong. Pengetahuan yang hendak diperoleh seorang ilmuwan hukum mustahil akan diperoleh tanpa ia sebelumnya mempunyai pra-pengetahuan. Misalnya jika hendak memperoleh pengetahuan

\footnotetext{
${ }^{22}$ B. Arief Sidharta (1), Op. Cit., hlm. 166.

${ }^{23}$ C.A. van Peursen, Fakta, Nilai, Peristiwa, Penerjemah A. Sonny Keraf, Gramedia, Jakarta, 1990, hlm. 59.

${ }^{24}$ lbid., hlm. 149.
} 
dari sebuah putusan Mahkamah Agung yang dipelajari, paling tidak harus mengetahui kedudukan putusan tersebut dalam tatanan hukum positif negara yang bersangkutan, selain sebelumnya harus sudah terbiasa dengan pemakaian bahasa hukum, pengertian hukum dan berbagai pengertian yang berkaitan dengan hukum. Selain itu juga dituntut harus mempunyai pengetahuan tentang hukum acara pada umumnya, misalnya apa yang dimaksud dengan pemeriksaan tingkat banding, pemeriksaan tingkat kasasi dan sebagainya. ${ }^{25}$

Beerling mengatakan bahwa sebenarnya tujuan dari suatu pertanyaan adalah tidak lain dari penjelasan tentang sesuatu yang sebenarnya telah diketahui dengan samar-samar, sekurang-kurangnya mau atau yakin akan menemukannya. ${ }^{26}$ Kegiatan memperoleh pengetahuan hukum yang lebih jelas dari pengetahuan yang sebelumnya masih samar-samar dan kurang jelas diperoleh melalui kegitatan interpretasi, yakni menemukan makna dari suatu aturan hukum.

IImu hukum sebagai disiplin ilmu yang mempelajari, memaparkan dan mensistematisasi satu sistem hukum tertentu dalam pengembanannya terkandung muatan interpretasi yang mengacu pada suatu sistem hukum yang berlaku dalam masyarakat tertentu. Oleh karena itu, kegiatan interpretasi dalam ilmu hukum menempati posisi sentral. Tujuan interpretasi dalam ilmu hukum selalu memaparkan aturan-aturan hukum yang dibentuk oleh otoritas yang berwenang, menentukan makna dan jangkauan yang terkandung di dalamnya dan menempatkannya dalam suatu sistem tatanan hukum, dengan menganalisis kata-kata yang digunakan sedemikian rupa sehingga ia siap untuk diterapkan pada peristiwa konkrit baik yang aktual maupun potensial untuk terjadi.

\section{Landasan Epistemologis dalam Penerapan Hukum}

Pada dasarnya kegiatan ilmu hukum itu merupakan kegiatan menawarkan penyelesaian masalah hukum konkrit yang timbul atau mungkin timbul dan harus dihadapi dalam masyarakat berdasarkan kerangka tatanan hukum yang ada. Artinya pengembanan ilmu hukum ini memiliki fungsi praktis, yakni terarah untuk menyelesaikan masalah hukum tertentu berdasarkan hukum

25 J.J.H. Bruggink, Refleksi tentang Hukum, Penerjemah B. Arief Sidharta, Citra Aditya Bakti, Bandung, 1999, hlm. 208.

${ }^{26}$ R.F. Beerling, Filsafat Dewasa Ini, Penerjemah Hasan Amin, Dinas Penerbitan Balai Pustaka, Jakarta, 1961, hlm. 11. 
positif tertentu, ${ }^{27}$ atau seperti pendapat Meuwissen yang menyebut bahwa ilmu hukum ini sebagai bentuk pengembanan hukum teoritis yang benar-benar praktis, artinya relevan untuk pembentukan dan penemuan hukum. ${ }^{28}$ Berdasarkan pengetahuan hukum yang dimiliki diharapkan setiap putusan yang dibuat para pengambil keputusan dapat dipertanggungjawabkan secara rasionalyuridis. Dengan kata lain, terhadap putusan tersebut diharapkan dapat ditempatkan dalam kerangka tatanan hukum yang berlaku sehingga memiliki landasan letigimasi dan terlaksananya penerapan hukum yang mempunyai tingkat akseptabilitas tinggi. Untuk dapat menghimpun, menata, memaparkan dan mensistematisasi teks hukum, sehingga dapat dijadikan dasar dalam mengambil keputusan, maka dilakukan analisis, pembentukan pengertianpengertian dan penggolongan (kategorisasi), serta klasifikasi dalam hukum dan untuk itu harus diinterpretasi. ${ }^{29}$

Selanjutnya dalam mengkaji objek ilmu hukum tentunya diharapkan jawaban yang benar dan bukan jawaban yang bersifat sembarangan. Masalah inilah yang dalam kajian filsafati termasuk wilayah kajian epistemologi, yang mengkaji persoalan sumber, asal mula dan sifat dasar pengetahuan, bidang, batas dan jangkauan pengetahuan serta validitas dan reliabilitas (reability) dari berbagai klaim tentang pengetahuan. Pengetahuan pada hakikatnya merupakan segenap apa yang kita ketahui tentang suatu objek tertentu, dari mulai pengetahuan sehari-hari sampai pada pengetahuan yang disebut ilmu. Pengetahuan dapat diibaratkan sebagai sumber jawaban bagi berbagai pertanyaan yang muncul dalam kehidupan manusia.

Dalam hukum terdapat teks hukum dan fakta dengan menggunakan model berpikir closed logical system bertumpu sangat kuat pada penalaran silogistik. Penetapan premis-premisnya, yakni baik dalam menetapkan fakta, juga yang yuridis relevan, maupun dalam menetapkan kaidah hukum yang terangkum dalam perundang-undangan sama-sama memandang keduanya sebagai objek yang dapat diamati dan ditangkap melalui pengamatan indrawi. Istilah closed logical system tersebut mengacu pada suatu sikap dan pendirian epistemologis tertentu, yaitu positivisme yang berasumsi bahwa bagaimana realitas sosial

\footnotetext{
${ }^{27}$ B. Arief Sidharta (1), Op.Cit., hlm. 134.

${ }^{28}$ D.H.M. Meuwissen, "Pengembanan Hukum", Pro Justitia, Penerjemah B. Arief Sidharta, Tahun XII, No. 1 Januari 1994, hIm. 66.

${ }^{29}$ Lihat Mochtar Kusumaatmadja dan B. Arief Sidharta, Op. Cit., hlm.7.
} 
(masyarakat dan manusia) dipahami adalah sama dengan bagaimana ilmu alam memperlakukan benda dan fenomena alam.

Pandangan bahwa penemuan hukum dapat dicirikan dengan model penalaran silogistik sangat kuat bertumpu pada pemikiran bahwa penyusunan premis-premis sungguh tidak perlu bersifat problematikal dan bahwa soal penetapan fakta-fakta dan juga teks hukum yang terangkum dalam peraturan perundang-undangan merupakan perkara yang mudah. Pandangan ini mengimplikasikan pengandaian tertentu tentang pengetahuan dan cara-cara memperoleh pengetahuan itu, yakni dengan hanya bertumpu pada kebenaran-kebenaran formal yang diproses melalui hukum logika deduksi. Model berpikir closed logical system nampak dalam kegiatan interpretasi yang dilakukan dengan menempatkan aturan-aturan hukum positif sebagai premis mayor dan kasus-kasus konkritnya sebagai premis minor. Berbeda dengan aliran hukum alam yang memiliki kekuatan argumen pada wacana validitas (legitimasi) hukum buatan manusia, maka kekuatan argumen positivistis hukum terletak pada aplikasi struktur norma positif itu ke dalam struktur kasus-kasus konkrit.

Masalah validitas (legitimasi) aturan tetap diberi perhatian, tetapi standar regulasi yang dijadikan acuannya adalah juga norma-norma hukum. Logikanya, norma hukum hanya mungkin diuji dengan norma hukum pula, bukan dengan norma non-hukum, dan karena itu logika berpikirnya dikenal dengan penalaran silogisme deduktif. Aturan-aturan hukum positif yang berfungsi sebagai premis mayor akan diterima sebagai doktrin yang aksiomatis, sepanjang ia mengikuti "the rule systematizing logic of legal science" yang memuat asas eksklusi, subsumsi, derogasi dan non-kontradiksi. ${ }^{30}$

Asas eksklusi, yaitu asas yang dengannya ilmu hukum mengandaikan sejumlah sumber legislatif tertentu bagi sistem, yang dengan itu mengidentifikasi sistem hukum tersebut. Sub-sumsi, yaitu asas yang dengannya ilmu hukum menetapkan hubungan hierarkhis di antara aturan-aturan hukum berdasarkan sumber legislatif yang lebih tinggi dan yang lebih rendah. Derogasi, yaitu asas yang berdasarkannya ilmu hukum menolak sebuah aturan atau bagian dari sebuah aturan, karena berkonflik dengan aturan lain yang berasal dari sumber legislatif yang lebih tinggi. Non-kontradiksi, yaitu asas yang berdasarkannya ilmu

${ }^{30}$ Shidarta, Era Hukum, No.2/Th.11/Januari 2004, hlm. 28-38. 
hukum menolak kemungkinan pemaparan sistem hukum yang di dalamnya orang dapat mengafirmasi eksistensi sebuah kewajiban dan pada saat yang sama juga non-eksistensi sebuah kewajiban yang mengkover situasi tindakan yang sama pada kejadian yang sama. ${ }^{31}$ Selanjutnya premis minor, yaitu fakta-fakta berupa kasus-kasus perilaku yang hendak dipertanyakan nilai normatifnya atau sering disebut peristiwa hukum.

Kata-kata dan peristilahan yang terdapat dalam teks hukum memiliki makna karena menyatakan isi dari pengertian yang dapat dinalar, yang dapat ditemukan melalui atau di dalam rasio, yang tersedia tuntas di dalam pemikiran, tanpa harus terlebih dahulu melewati tahapan pembentukan gambaran kenyataan. Penerapan istilah terjadi karena dalam suatu konteks fakta tertentu, dikenali ciri-ciri tertentu yang menunjukkan kesesuaian dengan ciri-ciri umum yang dimiliki pengertian-pengertian tersebut secara a priori. Apabila hakim sewaktu berhadapan dengan suatu situasi faktual berhasil mengenali kembali ciri-ciri khusus dari suatu pengertian yuridis tertentu, maka diandaikan bahwa selanjutnya pengertian-pengertian itu dapat diterapkan secara mekanistik.

Fakta (duduk perkara) yang ditempatkan sebagai premis minor dan melalui suatu penarikan kesimpulan, akan mempermudah dalam menemukan mengenai apakah bunyi hukumnya in concreto dalam suatu peristiwa hukum tertentu. Peragaannya dalam sidang-sidang pengadilan yang manaati ajaran hukum kaum positivis (yang dalam bahasa Hans Kelsen disebut reine rechtslehre) adalah sebagai berikut: apabila hakim menemukan bunyi hukumnya in abstracto, seperti misalnya pada rumusan Pasal 362 KUHP, bahwa premis mayor: "barangsiapa mengambil barang milik orang lain, sebagian atau seluruhnya, dengan maksud untuk menguntungkan diri sendiri atau orang lain secara melawan hukum, maka ia akan dihukum karena pencurian sebanyakbanyaknya $X$ tahun". Dalam pemeriksaan perkara sang hakim ini menerima bukti mengenai terjadinya suatu peristiwa hukum tertentu, dengan premis minor: "si $A$ mengambil sebagian dari milik orang lain dengan maksud untuk menguntungkan anaknya". Kesimpulan yang dapat ditarik dalam penalaran ini bahwa "si $\mathrm{A}$ harus dihukum karena mencuri”.

${ }^{31}$ B. Arief Sidharta (1), Op. Cit., hlm. 153. 
B. Arief Sidharta menyebut prinsip ini sebagai asas imputasi (mentautkan tanggung jawab/kewajiban), yaitu asas yang berdasarkannya berusaha menemukan hubungan antara dua hal atau lebih untuk menetapkan apa yang seharusnya menjadi kewajiban subjek tertentu dalam situasi konkrit tertentu, sehubungan dengan terjadinya perbuatan atau peristiwa atau keadaan tertentu, namun dalam kenyataan apa yang seharusnya terjadi itu tidak niscaya dengan sendirinya terjadi, dan karena itu rumus logikanya berbunyi: "Jika A (terjadi atau ada), maka seyogyianya B (terjadi)" (when $A$ is, B ouht to be, even though B perhaps actually is not). ${ }^{32}$

Dalam perkembangan ilmu hukum selanjutnya, bahwa untuk menemukan jawaban atas persoalan-persoalan hukum, yang jika dilihat dari aspek epistemologis, maka ada 2 (dua) pandangan besar, yaitu pandangan positivistik yang melahirkan ilmu empirik dan pandangan normatif yang melahirkan ilmu normatif. Sehubungan hal ini, maka ilmu hukum mempunyai dua sisi yang dimaksud. Pada satu sisi ilmu hukum menampilkan karakter khas sebagai ilmu normatif, sedangkan pada sisi lain ilmu hukum menunjukkan ciri-ciri empiris.

Sebagaimana ilmu pada umumnya, baik yang eksakta maupun yang sosial tujuannya adalah untuk memecahkan masalah (problem solving), untuk mencari jawaban apa, mengapa dan bagaimana. Dalam ilmu hukum yang harus dipecahkan adalah masalah-masalah hukum, konflik hukum atau kasus hukum. Oleh karena itu, menurut Sudikno Mertokusumo, setiap sarjana hukum harus menguasai kemampuan untuk memecahkan masalah-masalah hukum (the power of solving legal problem). Kemampuan tersebut mencakup kemampuan merumuskan masalah (legal problem identification), kemampuan memecahkan masalah (legal problem solving) dan kemampuan mengambil keputusan (decicion making). ${ }^{33}$

Lebih lanjut beliau mengatakan bahwa seorang sarjana hukum juga harus jeli dan tanggap terhadap perkembangan masyarakat. Janganlah bersikap konservatif formalistis dan a priori menutup mata terhadap perkembangan dalam masyarakat, melainkan berusaha mencari penyelesaian yuridis baru untuk mengatasi perkembangan-perkembangan yang terjadi dalam masyarakat. ${ }^{34}$

\footnotetext{
${ }^{32}$ B. Arief Sidharta (1), Op. Cit., hlm. 112.

${ }^{33}$ Sudikno Mertokusumo, Op. Cit., hlm. 32-33.

34 lbid., hlm. 34.
} 
Aspek epistemologis ilmu hukum disini tampak dalam proses penyelesaian kasus yang terbagi-bagi ke dalam beberapa langkah. Proses tersebut mencakup memaparkan, menginterpretasi, mensistematisasi bahan-bahan hukum yang terdiri asas-asas, aturan-aturan dan putusan-putusan hukum untuk menetapkan hukumnya yang berlaku atas masalah hukum yang timbul. Penyelesaian kasus tidak dimulai dengan aturan-aturan hukum, melainkan dimulai dengan masalah, yang berupa memaparkan sejumlah fakta, hubunganhubungan dan kejadian-kejadian yang di dalamnya tersembunyi satu atau lebih masalah yuridis.

G. van Der Burght dan J.D.C. Winkelman menjelaskan bahwa ada 7 (tujuh) langkah penyelesaian kasus, yaitu: ${ }^{35}$

1. Pemaparan singkat duduk perkara (skematisasi)

Langkah ini berkenaan dengan panataan sekelompok fakta-fakta dan kejadian-kejadian hingga mewujudkan suatu keseluruhan yang jelas dan berkerangka umum (bewujud sebuah ikhtisar) atau suatu gambaran umum menyeluruh (overzichtelijk).

2. Penterjemahan kasus ke dalam peristilahan yuridis (kualifikasi)

Fakta-fakta dan kejadian-kejadian yang telah tertata itu selanjutnya harus diterjemahkan ke dalam peristilahan yuridis berdasarkan aturan hukum yang mungkin terpilih untuk diterapkan. Langkah ini disebut tindakan mengkualifikasi. Pada fase ini, yang dilakukan adalah meletakkan hubungan antara fakta-fakta dan aturan-aturan hukum.

3. Seleksi aturan-aturan hukum yang relevan

Pada fase ini orang dikonfrontasikan (dihadapkan) pada pertanyaan: dimana dan dengan cara apa saya temukan aturan-aturan hukum yang dapat diterapkan pada kasus itu. Tempat menentukan dari sumber-sumber pengenalan (hukum) atau sumber hukum formal yang penting dari hukum kita adalah perundang-undangan, putusan hakim (peradilan) dan kepustakaan hukum dalam majalah-majalah dan buku-buku.

4. Analisis dan interpretasi aturan-aturan hukum

Tentang aturan-aturan hukum, hendaknya jangan hanya terfokus pada aturan-aturan hukum yang tercantum dalam pasal-pasal undang-undang

${ }^{35}$ Gr. Van der Burght \& J.D.C. Winkelman, "Penyelesaian Kasus", Pro Justitia, Penerjemah B. Arief Sidharta, Tahun XII, Nomor 1, Januari 1994, hlm. 35-53. 
saja. Banyak aturan hukum (yang dinamakan hukum tidak tertulis) yang tidak secara harfiah dapat ditemukan kembali dalam undang-undang, tetapi dalam perjalanan waktu dibentuk dan dikembangkan oleh peradilan. ${ }^{36}$ Segera setelah aturan-aturan hukum yang dapat diterapkan ditemukan dan diseleksi, maka isi (dari teks) dari aturan hukum itu harus ditetapkan dan diuraikan (dijelaskan, ditafsirkan).

Secara teknis metode-metode interpretasi dapat dibagi ke dalam metode penafsiran, yakni penafsiran gramatikal, sistematis, sejarah, teleologis, otentik dan metode konstruksi, yakni analogi, penghalusan hukum (rechtsvefijning), dan argumentum a contrario.

5. Penerapan aturan-aturan hukum pada kasus

Jika arti dari suatu aturan hukum dan akibat-akibat hukum yang terkait pada aturan hukum itu melalui penelaahan, analisis dan interpretasi telah ditetapkan, maka apa yang ditemukan itu harus diterapkan pada kasus yang tengah dihadapi.

6. Mengevaluasi dan menimbang argumentasi dan penyelesaian

Sering terjadi bahwa terhadap satu aturan hukum dapat diberikan lebih dari satu intepretasi. Untuk masing-masing interpretasi itu diajukan argumenargumen untuk mendukungnya. Pada umumnya dimungkinkan bahwa intepretasi yang bersangkutan telah turut diberikan oleh konsekuensikonsekuensi yang terkait padanya bagi (pihak-pihak dalam) kasus tersebut.

Hal menimbang pelbagai argumen yang berbeda dapat ditentukan (dipengaruhi) oleh sikap dari para yuris terhadap gejala-gejala dan masalah-masalah individual dan kemasyarakatan.

7. Formulasi penyelesaian

Jika setelah menjalani pelbagai fase, akhirnya penyelesaian untuk kasus itu ditemukan, maka penyelesaian itu harus dipaparkan dalam bahasa yang jelas dan dapat dipahami. Hal demikian itu disertai dengan suatu susunan yang berkerangka umum dan pembagian sarta penanganan butir demi butir dari kasus itu.

36 Dalam penerapan hukum, seorang hakim dituntut untuk selalu memperhatikan perasaan keadilan dalam masyarakat, karena semakin dinamisnya kehidupan masyarakat akan menyebabkan kaidah hukum selalu tertinggal, sehinga hakim harus menghidupkannya seiring dengan perubahan dan rasa keadilan masyarakat. Lihat Marwan Mas, Pengantar IImu Hukum, Ghalia Indonesia, Jakarta, 2004, hlm. 131. 
Ketujuh langkah ini, merupakan landasan dasar epistemologis yang perlu ditempuh oleh seorang hakim untuk menyelesaikan suatu perkara yang dihadapinya. Melalui langkah demikian, penerapan aturan-aturan hukum tertulis yang terdapat dalam peraturan perundang-undangan (law in book) akan dapat memenuhi perasaan keadilan yang berkembang dalam masyakat, karena memang dalam menerapkan hukum seorang hakim harus memperhatikan hukum yang hidup dalam masyarakat (living law)

\section{E. Penutup}

Berdasarkan paparan di atas sebelumnya, dapat ditarik point penting bahwa hukum bukan hanya merupakan sekumpulan peraturan yang hanya mengatur tingkah laku manusia, lebih dari hukum merupakan salah satu obyek studi. Hukum bukanlah barang yang tersedia begitu saja yang setiap saat oleh hakim dapat diterapkan terhadap fakta. Hakim ataupun aparat penegak hukum lainnya dalam menerapkan hukum terhadap suatu peristiwa yang terjadi membutuhkan ilmu hukum sebagai disiplin ilmu yang mempelajari, memaparkan dan mensistematisasi satu sistem hukum tertentu dalam pengembangannya terkandung muatan interpretasi yang mengacu pada suatu sistem hukum tertentu.

Dalam upaya menerapkan hukum, jelas memerlukan suatu metode tertentu dan metode ini haruslah dilakukan secara ilmiah. Kegiatan ilmiah di bidang hukum dilakukan dengan menggunakan berbagai sudut pandang dan pendekatan akan melahirkan berbagai disiplin ilmiah yang mandiri yang masingmasing objek telaahnya berbeda. Disiplin ilmiah yang dimaksud adalah kegiatan intelektual untuk secara rasional memperoleh pengetahuan dalam bidang hukum secara sistematis dan terikat pada aturan prosedur (metode) tertentu pula. Metode dimaksud adalah metode ilmiah yang merupakan prosedur dalam mendapatkan pengetahuan yang disebut ilmu. Prosedur untuk mendapat ilmu hukum secara benar yang dalam kajian filsafat termasuk wilayah kajian epistemologi. Aspek epistemologis ilmu hukum akan tampak jelas dalam proses penyelesaian kasus yang terbagi-bagi ke dalam beberapa langkah. Proses tersebut mencakup memaparkan, menginterpretasi, mensistematisasi bahanbahan hukum yang terdiri asas-asas, aturan-aturan dan putusan-putusan hukum untuk menetapkan hukumnya yang berlaku atas masalah hukum yang timbul. 


\section{DAFTAR PUSTAKA}

Arief Sidharta, B., "Disiplin Hukum: Tentang Hubungan Antara IImu Hukum, Teori Hukum dan Filsafat Hukum", Pro Justitia, Tahun XX, B. Arief Sidharta, No. 3, Juli 2002.

, Refleksi tentang Struktur IImu Hukum, Mandar Maju, Bandung, 2000.

Beerling, R.F., Filsafat Dewasa Ini, Penerjemah Hasan Amin, Dinas Penerbitan Balai Pustaka, Jakarta, 1961.

Bruggink, J.J.H., Refleksi tentang Hukum, Penerjemah B. Arief Sidharta, Citra Aditya Bakti, Bandung, 1999.

Burght, Gr. Van der. \& J.D.C. Winkelman, "Penyelesaian Kasus", Pro Justitia, Penerjemah B. Arief Sidharta, Tahun XII, Nomor 1, Januari 1994.

Flew, Anthony A Dictionary of Philosophy, Pan Books in association with The Macmillan Press, t.t.

Judistira K. Garna, Filsafat IImu, Primaco Akademika dan Judistira Garna Foundation, Bandung, 2006.

Judistira K. Garna, Filsafat IImu, Program Pascasarjana Unpad, Bandung, 2008.

, Teori Sosial Pembangunan I, Primaco Akademika dan Judistira Garna Foundation, Bandung, 2006.

, Filsafat IImu Sebuah Pengantar Populer, Cetakan Keduabelas, Pustaka Sinar Harapan, Jakarta, 1999.

Marwan Mas, Pengantar IImu Hukum, Ghalia Indonesia, Jakarta, 2004.

Meuwissen, D.H.M., "Pengembanan Hukum", Pro Justitia, Penerjemah B. Arief Sidharta, Tahun XII, No. 1 Januari 1994.

Mochtar Kusumaatmadja dan B. Arief Sidharta, Pengantar IImu Hukum, Buku I, Alumni, Bandung, 2000.

Peursen, C.A. van., Fakta, Nilai, Peristiwa, Penerjemah A. Sonny Keraf, Gramedia, Jakarta, 1990.

, Strategi Kebudayaan, Kanisius, Yogyakarta, 1988.

Pranarka, A.M.W., Epistemologi Dasar, Centre For Strategic and International Studies (CSIS), Jakarta, 1987.

Sudarminta, J., Epistemologi Dasar, Kanisius, Yogyakarta, 2002.

Sudikno Mertokusumo, Penemuan Hukum (Sebuah pengantar), Liberty, Jakarta, 2000.

Tengku Erwinsyahbana, "Sistem Hukum Perkawinan pada Negara Hukum Berdasarkan Pancasila", Jurnal IImu Hukum, Fakultas Hukum-Universitas Riau, Pekanbaru, 2012. 